\title{
Geospatial distributions of organochlorine insecticide in shallot agriculture land at Wanasari sub-district, Brebes regency, Central Java, Indonesia
}

\author{
Poniman ${ }^{1.4 *}$, Tri Retnaningsih Soeprobowowati ${ }^{1.2}$, Muhammad Helmi ${ }^{1.3}$ \\ ${ }^{1}$ Master Program in Environmental Science, School of Postgraduate Studies, Diponegoro University, \\ Semarang - Indonesia \\ ${ }^{2}$ Department of Biology, Faculty of Science and Mathematics, Diponegoro University Semarang, \\ Indonesia \\ ${ }^{3}$ Department of Oseanography, Faculty of Fisheries and Marine Sciences, Diponegoro University \\ Semarang, Indonesia \\ ${ }^{4}$ Indonesian Agricultural Environment Reasearch Institute (IAERI), Agriculture Agency of Indonesia
}

\begin{abstract}
The organochlorine insecticide is a POPs compound that was monitored according to the Stockholm convention in 2003 because it can cause environmental damage and threaten human health. The study of the distribution of organochlorine insecticides on onion farms has been carried out in the village area in Wanasari sub-District and Brebes Regency. This study was conducted in March-June 2019, with the scope of soil sampling, organochlorine insecticide residue analysis, and spline interpolation. To determine the number of organochlorine insecticide residues using the SNI 06-6991.1-2004 method, while to determine the distribution pattern using the Spline interpolation method with the ArcGIS 10.4. In preparing geospatial residues, we use the ratio of the maximum residual limit (MRLs) of each organochlorine active ingredient. These research sites can be categorized as severe pollution of OCPs insecticides. In this study OCPs residues (Aldrin, Lindane, and Heptachlor, DDT, Endrin, and Dieldrin) can be found with concentrations above the MRLs requirements. OCPs residues with very high range characteristics are shown by Aldrin, DDT, Endrin, and Dieldrin each of more than $50 \%$ of the total observed land area. Point numbers six detected all OCPs residues were observed with concentrations exceeding MRLs.
\end{abstract}

Keywords. Organochlorine, concentration and distribution, sallot agriculture, Brebes regency

\footnotetext{
*Corresponding author: poniman63ir@gmail.com
} 


\section{Introduction}

Organochlorine (OCPs) insecticides were widely used by agricultural systems in the past (during the green revolution). The use of OCPs insecticides is used massively through the Mass Guidance (BIMAS) and Mass Instruction (INMAS) programs. At that time the procurement of pesticides was subsidized by the government through the State Budget. The results are also speculatively proven by Indonesia's success in achieving food selfsufficiency in 1984. Now the insecticide has been banned in Indonesia since 2009 [1], except DDT which is still used limitedly to control mosquitoes that cause dengue fever in various countries $[2,3]$.

OCPs insecticide has a long half-life and therefore can last a long time in the [4] environment. OCPs insecticides are difficult to dissolve in water and fat-soluble. Because it is soluble in fat (lipophilicity), it is very potential for bioaccumulation in living things $[5,6]$. OCPs insecticides can cause cancer, genetic and teratogenic mutations, damage the immune system and endocrine system [6,7]. Therefore identification of the presence of OCPs insecticides is important to prevent negative impacts on the environment and also human health [8-11] and aquatic living things [12,13].

Brebes Regency is known as a producer of shallots in Indonesia and is recorded as a supplier of Indonesian onions around 60\% [14]. Wanasari Subdistrict is the largest shallot planting area which is 7,094 (24.44\%) of the planting area in Brebes with a production rate of 587,900 tons (21.56) of the total production of Brebes Regency [15].

Brebes Regency is known as the highest insecticide user in Indonesia even in Southeast Asia. [16] in its press release stated that as much as $30 \%$ of the circulation of pesticides in Indonesia circulated in Brebes. Edy Kusmartono (Head of Environment Office) of Brebes Regency stated that $50 \%$ of the shallot fields in Brebes had been damaged due to the use of pesticides for shallots that were very high [17].

Considering the effects caused by the OCPs insecticide residues, it is necessary to identify their presence on agricultural land. Monitoring the distribution, and effects of OPCs residues inland ecosystems, is considered important for assessing environmental ecological impacts [18-21]. Every pollution can be spatialized using geospatial model [2225], so that policies can be taken to mitigate pollution in the environment.

This study aims to determine the distribution of OCPs residue in shallot agricultural in Wanasari, Brebes Regency.

\section{Research Methods}

\section{Description of the research location}

The research area is an intensive area for planting shallots [15]. This region receives irrigation water flow from the Pemali river and therefore can be cultivated throughout the year. In general in this region, shallots are planted 3 times and corn or rice once and shallots twice. For most of the year, the land has never stopped planting except the time of tillage..

\section{Sampling Method}

Soil samples were taken at a depth of 0-20 cm, with a stainless steel soil drill. Each coordinate sampling point was taken as many as 5-7 sub-sample points, then from the subpoints were mixed in a large bucket of $10 \mathrm{~kg}$ volume, then taken as much as $0.5 \mathrm{~kg}$ and contained plastic to be brought under to the laboratory for analysis of OCPs insecticide residues. Each plastic must be given a sample identity label such as Sample number, 
coordinates, date of collection. Every coordinate point is recorded with its coordinates with the help of GPS MAP 78S type. The coordinates and village administrative areas are presented in Table 1.

Table 1. Point of Coordinate for soil sampling

\begin{tabular}{|c|c|c|c|}
\hline Point number & Latitude & Longitude (Village) & $\begin{array}{c}\text { Government } \\
\text { Administration }\end{array}$ \\
\hline 1 & 0652631 & 10903522 & Wanasari \\
\hline 2 & 0653348 & 10901261 & Siasem \\
\hline 3 & 0653202 & 10901283 & Pebatan \\
\hline 4 & 0652671 & 10901307 & Siasem \\
\hline 5 & 0652944 & 10901276 & Wanasari \\
\hline 6 & 0653408 & 10901423 & Pebatan \\
\hline 7 & 0652817 & 10901459 & Pebatan \\
\hline 8 & 0652718 & 10901391 & Pebatan \\
\hline 9 & 0652533 & 10901390 & Pebatan \\
\hline 10 & 0652486 & 10901484 & Pebatan \\
\hline 11 & 0652319 & 10901483 & Pebatan \\
\hline 12 & 0652255 & 10901566 & Siasem \\
\hline 13 & 0653015 & 10900263 & Siasem \\
\hline 14 & 0653308 & 10901276 & Wanasari \\
\hline
\end{tabular}

\section{Analysis of residues of OCPs insecticide in laboratory}

Analysis of insecticide residues was carried out at the Integrated Laboratory of the Indonesian Institute for Agricultural Research (Accreditation of Testing Laboratory Number: LP-556-IDN). Analysis residues of OCPs insecticide are based on SNI 06-6991.12004 [26] method. With the following order:

(1) Preparation of standard solutions and manufacture of working solutions for calibration curves.

(2) Extraction of the test material, ie Weigh $\pm 20 \mathrm{~g}$ of the test sample, insert it into the centrifuge tube. Then add $40 \mathrm{ml}$ of high purity acetone, shake using a whisk for 30 minutes. Rotate using a centrifuge at $2500 \mathrm{rpm}$ for 10 minutes. Transfer the liquid into a $300 \mathrm{ml}$ heart flask. Concentrate the liquid by using a vacuum system concentrator at a temperature $<35^{\circ} \mathrm{C}$ and a speed of $25 \mathrm{rpm}$, to a volume of $\pm 30 \mathrm{ml}$ then transfer it to a $500 \mathrm{ml}$ separating funnel. Add $100 \mathrm{ml}$ of $10 \% \mathrm{NaCl}$ solution to the separating funnel. Add $50 \mathrm{ml}$ of high-purity n-hexane, shake for 20 minutes using a whisk. Let stand until it forms 2 layers, namely the n-hexane layer and water. Fill a layer of water into a 250 
$\mathrm{ml}$ separating funnel, let the $\mathrm{n}$-hexane layer. Add $50 \mathrm{ml}$ of high-purity $\mathrm{n}$-hexane to the separating funnel containing a layer of water, shake for 20 minutes using a shaker. Let stand until it forms 2 layers, namely the n-hexane layer and water. Discard the water layer, combine the n-hexane layer with n-hexane. Add $100 \mathrm{ml}$ of distilled water and shake. Leave it to form 2 layers and discard the water layer Add $+5 \mathrm{~g}$ of anhydrous sodium sulfate powder until all the water is bound. Transfer n-hexane to $300 \mathrm{ml}$ heart flask. Concentrate n-hexane by using a concentrated vacuum system at a temperature of less than $35 \mathrm{oC}$ to a volume of $+5 \mathrm{ml}$.

(3) Washing process (clean up).

(4) Determination of the residual content of the insecticide using Gas Chromatography (GC). To calculate the amount of OCPs residues determined by the formula:

$$
A=\frac{c \times v \times f_{p}}{B}
$$

Where:

$\mathrm{A}=$ insecticide residue level, $\mu \mathrm{g} / \mathrm{g}$;

$\mathrm{B}=$ weight of test sample, $\mathrm{g}(10 \mathrm{~g})$;

$\mathrm{C}=$ insecticide residue level obtained from the calibration curve, $\mu \mathrm{g} / \mathrm{ml} ; \mathrm{V}=$ final dilution volume, $\mathrm{ml}(2 \mathrm{ml})$;

$\mathrm{fp}=$ dilution factor (if without dilution then $\mathrm{fp}=1$ ).

\section{Mapping the distribution residues of OCPs insecticides}

To maps the distribution of OCPs residues using ArcGIS software series 10.4 with a map scale of 1: 30,000. Distribution pattern distribution uses the spline interpolation method, with five categories of scale range, namely: (1) very low, (2) low, (3) moderate, (4) high, and (5) very high. To determine the magnitude of the range of values is to subtract the value of BMR-LoD divided by two for each active ingredient. The amount of BMR according to [27] is 0.0290 (aldrin); $0.0100 \mathrm{mg} / \mathrm{kg}$ (Lindane); $0.0390 \mathrm{mg} / \mathrm{kg}$ (heptachlor); $0.0110 \mathrm{mg} / \mathrm{kg}$ (dieldrin); $0.0075 \mathrm{mg} / \mathrm{kg}$ (endrin); and $0.0150 \mathrm{mg} / \mathrm{kg}$ (DDT).

Spline interpolation is a method for analyzing geostatistical data in interpreting values based on data from sampling points. This method is used to estimate the number of organochlorine residuals at the unsampled point based on information from organochlorine residues from the surrounding sampled points. Mentioned by [28] the influence of the value of the closest point is greater than the value of the far point.

Spline interpolation can be used to estimate values using mathematical functions and can minimize the curvature that connects the values of the observed sample point [29]. By doing mapping using the help of ArcGIS spline interpolation can be easily done [30]. Geospatial can provide an overview of each observation and can be associated with the extent of the impact caused [31-34].

\section{Results and Discussion}

Of the nine active organochlorine insecticide ingredients tested, six of them were detected in the test sample. The six active ingredients are aldrin, lindane, heptachlor, dieldrin, endrin, and DDT. All samples that have detected active residues of their active ingredients show residual rates above BMR. Aldrin residues were detected between $<$ LoD- $0.4442 \mathrm{mg} /$ $\mathrm{kg}$ detected at 11 observation points. Dieldrin was detected at ten points with residues between $<$ LoD- $0.0818 \mathrm{mg} / \mathrm{kg}$. Meanwhile DDT and Endrin residues were detected at nine and eight observation points ranging between $<$ LoD- $0.1728 \mathrm{mg} / \mathrm{kg}$ and $<$ LoD-0.0771 $\mathrm{mg} / \mathrm{kg}$. Whereas Lindan and Heptachlore residues were only detected at one observation 
point that was equal to $0.3222 \mathrm{mg} / \mathrm{kg}$ and $0.2144 \mathrm{mg} / \mathrm{kg}$. Point number 6 was detected to contain six active ingredients above the MRLs determination based on [27]. The performance of organochlorine residues is presented in Table 2.

The discovery of organochlorine insecticide residues in shallot planting soils provided certainty that OCPs residues could be bioaccumulated $(6,7]$, as well as providing information that organochlorine insecticides were used at least at this location.

Organochlorine insecticides in Indonesia have been banned from limited use since 1989 and has been permanently banned since 2009 [1].

Table 2. Residu of OCPs insecticide in the shaloot fields of Wanasari, Siasem, and Pebatan village, at Wanasari subdictrict, Brebes regency 2019

\begin{tabular}{|c|c|c|c|c|c|c|}
\hline \multirow{2}{*}{$\begin{array}{c}\text { Point } \\
\text { Nunber }\end{array}$} & \multicolumn{6}{|c|}{ Residues } \\
\hline & Aldrin & Lindane & Heptachlore & Dieldrin & Endrin & DDT \\
\hline & \multicolumn{6}{|c|}{ - } \\
\hline 1 & 0.1389 & $<\mathrm{LoD}$ & $<\mathrm{LoD}$ & 0.0365 & 0.0373 & $<$ LoD \\
\hline 2 & 0.2611 & $<\mathrm{LoD}$ & $<\mathrm{LoD}$ & 0.0235 & 0.0242 & 0.0720 \\
\hline 3 & 0.2681 & $<\mathrm{LoD}$ & $<\mathrm{LoD}$ & 0.0487 & $<\mathrm{LoD}$ & 0.1387 \\
\hline 4 & 0.2134 & $<\mathrm{LoD}$ & $<\mathrm{LoD}$ & $<\mathrm{LoD}$ & $<\mathrm{LoD}$ & 0.1031 \\
\hline 5 & 0.0961 & $<\mathrm{LoD}$ & $<\mathrm{LoD}$ & 0.0195 & $<\mathrm{LoD}$ & $<$ LoD \\
\hline 6 & 0.1057 & 0.3222 & 0.2144 & 0.0465 & 0.0471 & 0.1048 \\
\hline 7 & 0.1311 & $<\mathrm{LoD}$ & $<\mathrm{LoD}$ & 0.0483 & 0.0538 & 0.0992 \\
\hline 8 & 0.1836 & $<\mathrm{LoD}$ & $<\mathrm{LoD}$ & 0.0537 & 0.0603 & 0.1728 \\
\hline 9 & 0.4442 & $<\mathrm{LoD}$ & $<\mathrm{LoD}$ & 0.0491 & 0.0519 & 0.0953 \\
\hline 10 & 0.2924 & $<\mathrm{LoD}$ & $<\mathrm{LoD}$ & 0.0818 & 0.0771 & 0.1174 \\
\hline 11 & 0.1883 & $<\mathrm{LoD}$ & $<\mathrm{LoD}$ & 0.0588 & 0.0547 & 0.1310 \\
\hline 12 & $<\mathrm{LoD}$ & $<$ LoD & $<\mathrm{LoD}$ & $<$ LoD & $<$ LoD & $<$ LoD \\
\hline 13 & $<\mathrm{LoD}$ & $<\mathrm{LoD}$ & $<\mathrm{LoD}$ & $<\mathrm{LoD}$ & $<\mathrm{LoD}$ & $<\mathrm{LoD}$ \\
\hline 14 & $<$ LoD & $<\mathrm{LoD}$ & $<\mathrm{LoD}$ & $<\mathrm{LoD}$ & $<$ LoD & $<$ LoD \\
\hline $\left.\mathrm{LoD}^{*}\right)$ & 0.0029 & 0.0024 & 0.0024 & 0.0042 & 0.0045 & 0.0039 \\
\hline MRLs $\left.^{* *}\right)$ & 0.0290 & 0.0100 & 0.0390 & 0.0110 & 0.0075 & 0.0150 \\
\hline
\end{tabular}

The total area of this study $\pm 1,853$ ha, consisting of 14 soil sampling points from three villages (Wanasari, Siasem, and Pebatan), Wanasari Sub-District, Brebes Regency.

After interpolation, most of the land area is categorized as heavily polluted. Distribution of Aldrin contamination, the widest area experiencing pollution is a very high category of 1183.51 ha. The same thing also happened to the distribution of pollution in Dieldrin, DDT, and Endrin each covering 1178.06 ha; 1120.76 ha; and 1084.42 ha. Meanwhile, Lindane and Heptachlore residues mostly showed very small residues of 1239.26 ha and 1241.50 ha. The low contamination of Lindane and Heptachlor is estimated that indeed these two OCPs are not widely used in this land.

A large number of residues OCPs of DDT were found by [35] in Wonosobo vegetable agriculture, and even residues of OCPs insecticides were also found in carrot, cabbage and potato products [36]. Soil and vegetable products in Magelang Regency were found by 
OCPs residue [37]. Not only in Indonesia, OCPs residues around the city of Zhangzhou China by [38], Sokoto Nigeria [39].

The distribution of the OCPs residual can be mapped as follows (Figure 1). Each pollution has a certain area based on spline interpolation mapping [22, 23, 25, 31, 33]. The very high pollution residue categories interpreted in red are shown by Aldrin $64.90 \%$ (Figure1.a), DDT 61.46\% (Figure 1.d), Endrin 59.49\% (Figure 1.e), and Dieldrin $64.60 \%$ (Figure1.f). This data is interesting considering the OCPs residue should have been 0 (zero) because it can reduce environmental quality and reduce product quality.

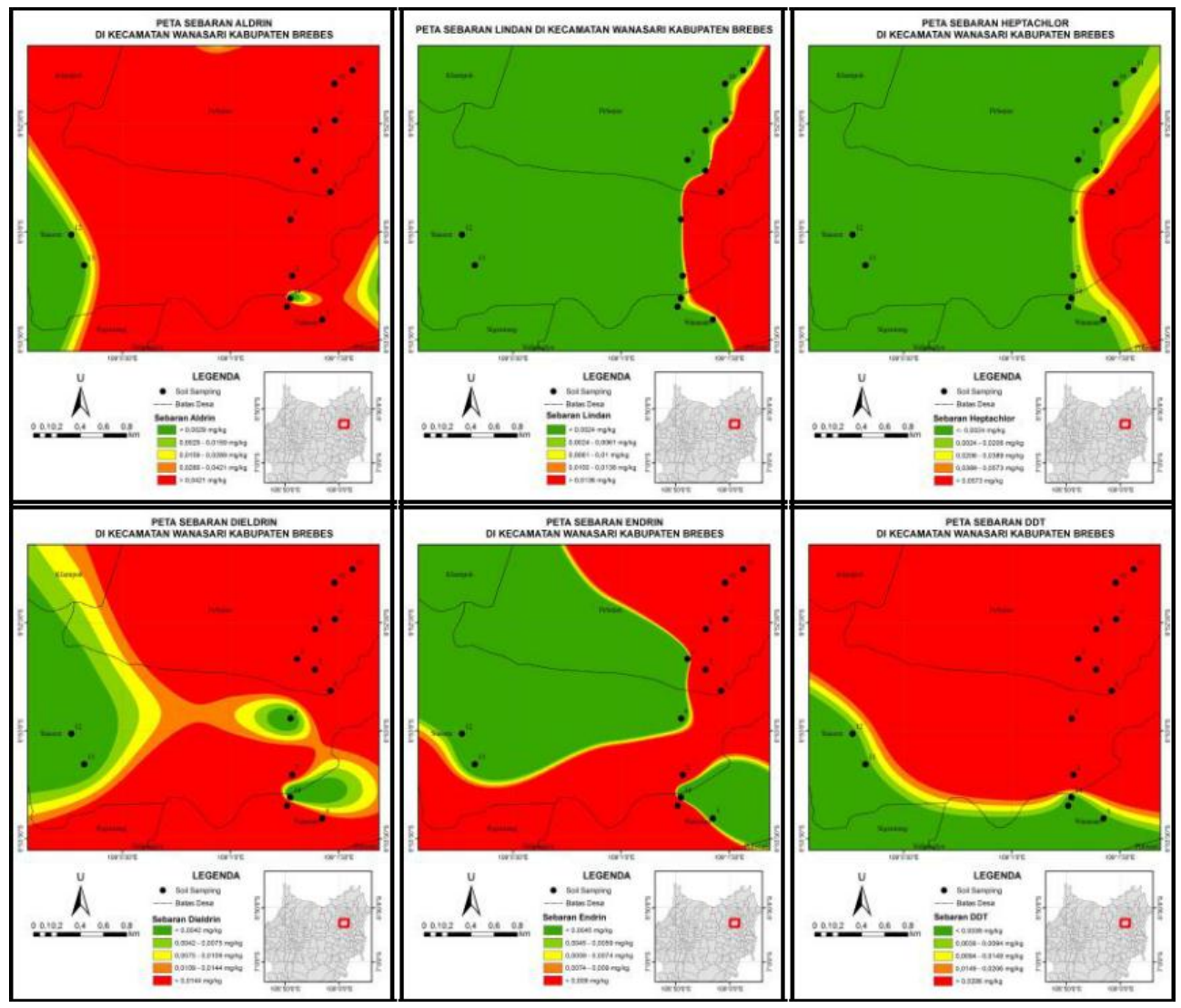

Figure 1. Clockwise in the same direction is the distribution of OCPs insecticide residues (a) Aldrin, (b) Lindane, (c) Heptachlore, (d) DDT, (e) Endrin, and (f) Dieldrin

\section{Conclusion}

These research sites can be categorized as severe pollution of OCPs insecticides. In this study OCPs residues (Aldrin, Lindane, Heptachlore, DDT, Endrin, and Dieldrin) can be found with concentrations above the MRLs requirements. OCPs residues with very high range characteristics are shown by Aldrin, DDT, Endrin, and Dieldrin each of more than $50 \%$ of the total observed land area. Point numbers six detected all OCPs residues were observed with concentrations exceeding MRLs. 


\section{References}

1. Undang-undang Republik Indonesia.Nomor 19 Tahun 2009. Tentang Pengesahan Stockholm Convention On Persistent Organic Pollutants (Konvensi Stockholm Tentang Bahan Pencemar Organik yang Persisten).(2009)

2. Roberts, D.R., L. L. Laughlin, P.Hsheih, and L.J. Legters. DDT, Global Strategies, and Malaria Control Crisis in South America. Emerging Infectious Diseases. Vol. 3, No. 3, July-September 1997. Pp: 295-302 (1997)

3. Quinones, M.L., D.E. Norris, J.E. Conn, M. Moreno, T.R. Burkot, H.Bugoro, J.B. Keven, R.Cooper, G.Yan, A.Rosas, M.Palomino, M.J.Donnelly, H.D.Mawejje, A.Eapen, J.Montgomery, M.B. Coulibaly, J.C.Beier, and A. Kuma. Insecticide Resistance in Areas under Investigation by the International Centers of Excellence for Malaria Research: A Challenge for Malaria Control and Elimination. Am. J. Trop. Med. Hyg., 93 (Suppl 3): pp. 69-78 (2015)

4. El-Mekkawi, H., Diab, M., Zaki, M. and Hassan.. A. Determination of Chlorinated Organic Pesticides in Water, Sediments and Fish from Private Fish Farms from Abbassa and Sahl Al-Husainia, Sharkia Governorate Aust. Journal of Basic Applied Science 3(4): 4376-4383. (2009)

5. Afful, S., Anim, A. and Serfor-Armal, Y.. Spectrum of Organochlorine Pesticide Residues in Fish Samples from the Densu Basin Resource. Journal of Environmental Earth Science 2 (3): 133-138. (2010)

6. Harrad, S.. Persistent organic pollutans. A John Wiley and Sons, Ltd., Publication, West Sussex, UK (2010)

7. IPEP (International POPs Elimination Project). POPs in China. Pesticide EcoAlternatives Center (PEAC)., Kunming, Yunnan. www.ipen.org. (2006).

8. Lee W Y, Iannucci-Berger W A, Eitzer B D. Plant uptake and translocation of airborne chlordane and comparison with the soil-to-plant route J. Chemosphere, 53: 111121. (2003)

9. Barriada-Pereira M., Gonzalez-Castro M. J , Muniategui-Lorenzo. Organochlorine pesticides accumulation and degradation products in vegetation samples of a contaminated area in Galicia (NW Spain) J. Chemosphere, 58: 1571-1578. (2005)

10. Schulz, R. Field Studies on Exposure, Effect and Risk Mitigation of aquatic non-point Source Insecticide Pollution a Review. J. environ Qual. 33:419-425 (2012)

11. Lalah, J., Yugi, P., Jumba, I. and Wandiga, S. Organochlorine Pesticide Residues in Tana and Sabaki Rivers in Kenya. Bull Environ Contam. Toxico 171:298-301. (2011)

12. Reichenberger S, Bach M, Skitschak A, Frede H-G. Mitigation strategies to reduce pesticide inputs into ground-and surface water and their effectiveness: a review. Sci Total Environ 384 (1): 1-35 (2007)

13. Zhang M., Rachael Goodhue. Agricultural Pesticide Best Management Practices Report A Final Report for the Central Valley Regional Water Quality Control Board Award \# 06-262-150-0 Task Eight Principal Investigators. The University of California, Davis Agricultural GIS (AGIS) Laboratory. https://www.researchgate.net/profile/Kimberly Steinmann/ publication/265574604

14. Pusat Data dan Sistem Informasi Pertanian-KementerianPertanian. Komoditas Pertanian Sub Sektor Hortikultura. Outlook Bawang Merah. Sekretariat JenderalKementerian Pertanian. 90 hal. (2016). https://www.google.com/search?ie=utf$\underline{8 \& o e=u t f-8 \& \mathrm{cso}=1} \&$ q $=$ produksi + bawang + merah + nasional

15. BPS Kabupaten Brebes. Kabupaten Brebes dalam angka 2018. 318 halaman (2018)

16. Croplife Indonesia. CropLife dorong petani perhatikan 5 hal aplikasi pestisida. (2009) 
17. Nasional Tempo. Separuh lahan pertanian di Brebes rusak akibat pestisida. (https://nasional.tempo.co/read/794853/separuh-lahan-pertanian-di-brebes-rusak-akibatpestisida/full\&view=ok), (2018).

18. Muller, K., Bach, M. Hartman, H., Spiteller, M. and Frede, H. Point and Non-point Source Pesticide Contamination in the Zwester Ohm, Germany. J. Environ Qual. 31:309-312. (2011)

19. Batch, M. Hubber, A., and Frede, H. Input Pathways and River Load of Pesticides in Germany - A Rational Scale Modeling Assessment. Water Sc. Tech. 43:261-268. (2010)

20. Liess, M. Schulz, R; Liess MHD, Rother, B. and Kreuzig, R Determination of Insecticide Contamination in Agricultural Read Water Streams. Water Res.33:229-235. (2009)

21. Krenger, J. Pesticide in Stream Water Within an Agricultural Catchment in Southern Sweden. 2000-2006. Sci Total Environ 216:227-235 (2008)

22. Hartoko1 A., M. Helmi , M. Sukarno , dan Hariyadi. Spatial Tsunami Wave Modelling for the South Java Coastal Area, Indonesia. International Journal of GEOMATE, Sept., 2016, Vol. 11, Issue 25, pp. 2455-2460 Geotec., Const. Mat. \& Env. Japan. (2016)

23. Hilmi, M., A. Satriadi, A.A.D. Suryoputro, J. Marwoto, H.S. Hariyadi. Rehabilitation Priority Area on Death Coral Using ased Modeling Approach at Parang Islands, Karimunjawa National Park, Indonesia. International Journal of Civil Engineering and Technology (IJCIET) Volume 9, Issue 11, November 2018 Available online at http://www.iaeme.com/ijciet/issues. (2018)

24. Nurdin, N., M. Helmi , R.Y. Setiawan, M. Zainuddin, Rustam, Agus, dan M. Akbar. Landsat Capability to Mapping of Total Solid Suspended (TSS) and Coastal Ecosystem. The International Archives of the Photogrammetry, Remote Sensing and Spatial Information Sciences, Volume XLII-4/W16,. $6^{\text {th }}$ International Conference on Geomatics and Geospatial Technology (GGT 2019), 1-3 October 2019, Kuala Lumpur, Malaysia. (2019)

25. Muhammad Helmi, Purwanto, W. Atmodjo and P. Subardjo. Benthic Diversity Mapping and Analysis Base on Remote Sensing and Seascape Ecology Approach at Parang Islands, Karimunjawa National Park, Indonesia. International Journal of Civil Engineering and Technology (IJCIET) Volume 9, Issue 11, November 2018, pp. 227235.http://www.iaeme.com/ijciet/issues.asp?JType=IJCIET\&VType=9\&IType=11. (2018).

26. Badan Standarisasi Nasional-BSN. SNI 06-6990.1-2004. Tanah-Bagian 1: Cara uji pestisida organoklorin secara ekstraksi menggunakan pelarut n-heksan dengan Kromatografi Gas-Spektrofotometer Massa (KG-SM) (2004)

27. Alberta Tier 1 Soil and Groundwater Remediation Guidelines. Land Policy Branch, Policy and Planning Division. 198 pp. https://www.alberta.ca/ministry-environmentparks.aspx. (2009)

28. Burrough P.A. and McDonnell R.A. Principles of Geographical Information systems Oxford University press, New York, 333p. http://dds.cepal.org/infancia/guidetoestimating-child-poverty/bibliografia/capitulo. (1998)

29. Binh, T. Q., and Thuy, N. T.. Assessment of the influence of interpolation techniques on the accuracy of digital elevation model. VNU Journal of Science, Earth Sciences, 24: 176-183. (2008)

30. Anderson, S.. An evaluation of spatial interpolation methods on air temperature in Phoenix, AZ. Department of Geography, Arizona State University Tempe, 85287-0104. (2002)

31. Setyawidati, N., A.H.Kaimuddin, I.P. Wati, M. Helmi, I. Widowati, N. Rossi, P.O. Liabot, and V. Stiger-Pouvreau. Percentage cover, biomass, distribution, and potential 
habitat mapping of natural macroalgae, based on high-resolution satellite data and in situ monitoring, at Libukang Island, Malasoro Bay, Indonesia. J Appl Phycol 30:159$171.9^{\text {th }}$ Asia Pacific Conference On Algal Biotechnology - Bangkok. (2018)

32. Wirasatriya, A., H. Kawamura, M. Koch, and M. Helmi. Satellite-borne detection of high diurnal amplitude of sea surface temperature in the seas west of the Tsugaru Strait, Japan, during Yamase wind season. Journal of Oceanography 75:23-36. https://doi.org/10.1007/s10872-018-0481-1. (2019).

33. Fitriyanto, B.R., M. Helmi, and Hadiyanto. Analyzing spatiotemporal types and patterns of urban growth in watersheds that flow into Jakarta Bay, Indonesia. Remote Sensing Applications: Sosiety and Environment 14:170-177. Journal.homepage: www.elsivier. com/locate/rsase. (2019).

34. Helmi M., Y.H. Pholandani, H. Setiyono, A. Wirasatriya, W. Atmodjo, R. Widyaratih, A.A.D. Suryoputro. Assessment at Coastal Area of Kalianda Sub District, South Lampung District, Lampung Province, Indonesia. International Journal Of Scientific and Technology Research Volume 9, Issue 03, March 2020 ISSN 2277-8616 1803. (2020).

35. Indratin, Poniman, dan Sukarjo. Sebaran residu Dichloro Diphenyl Trichloroethane (DDT) di lahan pertanian Kabupaten Wonosobo. Prosiding Seminar Nasional Hasil Penelitian Pertanian VII “ Peranan Hasil Penelitian Pertanian dalam Mewujudkan Kedaulatan Pangan untuk Kesejahteraan Petani”. Fakultas Pertanian. Universitas Gadjah Mada. hal: 236-244. (2017)

36. Poniman, Indratin, dan M.T. Sutriadi. Residu Pestisida di Lahan Sayuran Dataran Tinggi Dieng. Prosiding Seminar Nasional Peningkatan Produktivitas Sayuran Dataran Tinggi. Balai Besar Sumberdaya Lahan Pertanian. hal. 228-236. (2013)

37. Poniman and Indratin. Residues of organochlorine and organophosphate in vegetable and soil on Andosols of Magelang Regency. Jurnal Tanah dan Iklim (edisi khusus) (2015)

38. Yang Dan, Qi Shi-Hua, Zhang Jia-Quan, Tan Ling-Zhi, Zhang Jun-Peng, Zhang Yuan, Xu Feng, Xing Xin-Li, Hu Ying, Chen Wei, Yang Jun-Hua and uX Mei-Hui. Residues of Organochlorine Pesticides (OCPs) in Agricultural Soils of Zhangzhou City, China. Journal Pedosphere 22 (2): 178-189. (2012)

39. Osesua, B.A., Tsafe, A.I., Birnin-Yauri, U.A. and Sahabi, D.M. Profil Pestisida OrganokrorinDegradasi Di Tanah Pertanian Irigasi WurnoWilayah Di Negara Sokoto, Nigeria. International Journal of Advanced Academic Research Sciences, Technology and Engineering Vol. 4, Issue 1. (2018.) 